PRACE GEOGRAFICZNE

zeszyt 164, 2021, 91-103

doi: 10.4467/20833113PG.21.001.13426

Instytut Geografii i Gospodarki Przestrzennej UJ

Komisja Geograficzna, Polska Akademia Umiejętności

Wydawnictwo Uniwersytetu Jagiellońskiego

\title{
PROBLEMATYKA DEFINICJI MIASTA I LUDNOŚCI MIEJSKIEJ W CHIŃSKIEJ REPUBLICE LUDOWEJ
}

\author{
Mirostaw Wylon
}

\section{Problems of city definition and urban population in the People's Republic of China}

\begin{abstract}
Present urbanization processes are characterized by unusual spontaneity, reflected in numerous problems in defining urban population and determining real city boundaries. Of particular interest, from a scientific point of view, is the case of China, where a considerable dynamics of socio-economic transformations, as well as political and administrative issues are reflected in a complex urban structure. Serious complications in determining the real Chinese urban population number, or determining real city boundaries are the complicated administrative division, manifested by an unnatural size of the cities, and the inclusion of rural population under their urban jurisdiction. In addition, the question of social duality between the countryside and the city,caused by the Hukou register system, seriously hampers estimations of a city resident number. Mass migration from the countryside to cities, in most cases without updating the Hukou system, resulted in a lack of complete and accepted statistics concerning the population of Chinese cities. It is also worth mentioning, that rural migrants in urban areas are often a secondary category of citizens facing socio-economic discrimination, leading to a visible and tangible polarization among Chinese urban residents.
\end{abstract}

Keywords: city, urban population, China, administrative border, Hukou system

Zarys treści: Współczesne procesy urbanizacyjne cechują się niezwykłą żywiołowością, której odbiciem są liczne problemy w definiowaniu ludności miejskiej i wyznaczaniu rzeczywistych granic miast. Szczególnie interesujący z naukowego punktu widzenia jest przypadek 
Chin, gdzie dynamika przekształceń społeczno-ekonomicznych oraz kwestie polityczno-administracyjne mają konsekwencje w skomplikowanej strukturze miejskiej. Poważnym utudnienie przy wyznaczaniu właściwej liczby chińskiej ludności miejskiej lub określaniu rzeczywistych granic tamtejszych miast jest skomplikowany podział administracyjny, objawiający się nienaturalnym niekiedy rozmiarem miast oraz włączaniem ludności wiejskiej pod miejską jurysdykcję. Ponadto, kwestia podziału społecznego między wsią a miastem, który jest skutkiem istnienia swoistego systemu meldunkowego Hukou, poważnie utrudnia dokładne oszacowanie liczby rezydentów miejskich. Masowa migracja ze wsi do miast, w większości przypadków niepociągająca za sobą aktualizacji Hukou, w przypadku migrantów wpłynęła na brak pełnych i akceptowanych statystyk liczby ludności chińskich miast. Warto również wspomnieć, że ci migranci na obszarach miejskich często stanowią drugorzędną kategorię obywateli doświadczającą tam społeczno-ekonomicznej dyskryminacji, co prowadzi do widocznej i odczuwalnej polaryzacji mieszkańców miast chińskich.

Stowa kluczowe: miasto, ludność miejska, Chiny, granica administracyjna, system Hukou

\section{Wstęp}

Miasto jest wytworem człowieka, środowiskiem jego życia, oraz miejscem, w którym koncentrują się różnorodne formy ludzkiej działalności. Obecnie jesteśmy świadkami gwałtownie rosnącej liczby miast w większości krajów świata (Bracken 2012). Ten szybki rozwój osadnictwa miejskiego skutkuje powstawaniem wielu różnorodnych jego form, m.in takich jak: konurbacje, aglomeracje policentryczne i monocentryczne, obszary metropolitarne, megalopolis itd. (Eberhardt 2010). Można więc uznać, że miasto jest niczym żywy organizm, który kurczy się lub rozrasta, przechodząc przez etapy swego rozwoju. Fenomen miasta sprawia, że nie ma uniwersalnej definicji tej jednostki osadniczej. Niemalże każde państwo ma własne, często dość sztywne, definicje miasta. Ta różnorodność powoduje liczne komplikacje w badaniach obszarów miejskich. Najczęściej obszar miasta sprowadzany jest do jego granic administracyjnych, co jednak w zdecydowanej większości przypadków nie odpowiada jego rzeczywistej wielkości. Obszary miejskie są pod ciągłym wpływem różnorodnych procesów, wpływających na ich rozwój, stagnację, a niekiedy nawet obumieranie, doprowadzając tym samym do licznych zmian jego prawdziwej powierzchni i liczby ludności. Zjawiska takie jak urbanizacja, suburbanizacja, dezurbanizacja, reurbanizacja, aglutynacja, urban sprawl itd. kształtują obecnie miejską sieć osadniczą. Sytuacja ta dotyczy niemal każdego państwa, w którym proces urbanizacji zachodzi, lecz ze względu na dynamikę jest to najwyraźniej widoczne w największych krajach, szybko rozwijających się, takich jak Indie, Brazylia czy właśnie Chiny (Szymańska 2015).

Do określenia rzeczywistych granic miast i ich porównywania wykorzystuje się najczęściej dwie definicje: obszar miejski (forma fizyczna) i obszar metropolitalny (forma funkcjonalna lub ekonomiczna) (Demographia, Definition of Urban Terms 2008). 
Obszar miejski (urban area) - jest to obszar miejskiej zabudowy, najczęściej wyznaczany za pomocą zdjęć satelitarnych. Chociaż nie pokrywa się on zwykle z oficjalnymi granicami administracyjnymi miasta, często jednak jest wykorzystywany w różnorodnych opracowaniach naukowych czy rządowych. W większości przypadków obszar ten wykracza poza granice jurysdykcyjne miasta, często obejmując również sąsiednie jednostki. W Chinach np. w kilku przypadkach największych miast, takich jak Szanghaj, Pekin, Czungking, urban area obejmuje mniejszy obszar niż ich granice administracyjne (Demographia, Definition of Urban Terms 2008).

Obszar metropolitalny (metropolitan area) - stanowi przestrzeń funkcjonalną obejmującą zarówno tereny zabudowy miejskiej, jak i powiązane z nim zaplecze gospodarcze. Relacje gospodarcze kreowane są głównie przez dojazdy do pracy znajdującej się w obszarze miejskim. Obszar metropolitalny jest więc wynikiem powiązań występujących na rynku pracy, obejmuje zatem większą powierzchnię i więcej ludności niż obszar miejski (Demographia, Definition of Urban Terms 2008).

\section{Definicja miasta i ludności miejskiej w kontekście Chin}

Jednym z najlepszych przykładów skomplikowanego podejścia do kwestii definiowania miasta są Chiny. Według oficjalnych definicji miasto w ChRL jest jednostką administracyjną, oficjalnie wyznaczoną. Kryteriami tego wyznaczania są funkcje polityczno-administracyjne, poziom rozwoju gospodarczego i wielkości populacji miasta (Song, Zhang 2012; Chan 2000).

W Państwie Środka oficjalnie miasta dzielą się na 3 klasy (Zhang, Song 2012):

- miasta wydzielone (municipalites), niekiedy zwane miastami na poziomie prowincji (provincial level cities) - Pekin, Szanghaj, Tiencin i Czungking;

- miasta na poziomie prefektury (prefecture level cities);

- miasta na poziomie powiatu/hrabstwa (county level cities).

Najwyżej w hierarchii administracyjnej usytuowane są więc cztery miasta wydzielone, zarządzane podobnie jak prowincje, niżej znajdują się miasta na poziomie prefektury, najniżej zaś miasta na poziomie powiatu. Wyższy status w podziale administracyjnym wpływa na większe możliwości polityczne i dostęp do zasobów, dlatego władze lokalne często starają się podnieść status ośrodka miejskiego (Song, Zhang 2012; Kamal-Chaoui, Leman 2009). W 2000 r. w ChRL oficjalnie znajdowało się 659 miast, z czego $259(39,3 \%)$ było miastami na poziomie prefektury, a 400 na poziomie powiatu $(60,7 \%)$. W 2015 r. na 652 ośrodki miejskie już 291 (44,6\%) zaliczono do poziomu prefektury, a $361(55,4 \%)$ do poziomu powiatu (National Bureau of Statistics of China) ${ }^{1}$. Według statystyk Chińskiego Biura Statystycznego (NBSCh)

\footnotetext{
${ }^{1}$ Bez uwzględnienia czterech miast wydzielonych (ang. municipalities) - Pekinu, Szanghaju, Tiencinu i Czungkingu.
} 
w latach 2000-2015 liczba miast spadła o 7, co w żaden sposób nie oddaje rzeczywistych zmian w ich sieci osadniczej. W tym czasie liczba ludności miejskiej wzrosła z 460,4 mln osób do 775,4 mln, zaś populacja miast milionowych podwoiła się z 175,6 mln rezydentów do 344,2 mln. Pojawiło się wówczas 45 miast milionowych, osiągając w 2015 r. ogólną liczbę 109 (World Urbanization Prospects: The 2018 Revision).

Podstawowym problemem badaczy chińskiej urbanizacji jest wyznaczenie rzeczywistego obszaru miast, a więc również wielkości populacji miejskiej. Chińskie miasta są jednostkami znacznie różniącymi się od tych w krajach zachodnich ze względu na swój rozmiar i rozległe obszary wiejskie, jakie obejmują. Wyzwania związane z określaniem miast i ludności miejskiej w Chinach są kwintesencją złożonych danych statystycznych i przyjętych rządowych definicji (Chan 2000, 2016). Już w połowie lat 90. XX w. Kojima (1995) zwracał uwagę na niedoszacowanie danych dotyczących liczby stałych mieszkańców obszarów miejskich i poziomu urbanizacji Chin. Zdaniem tego autora dokładne określenie liczby ludności miejskiej powinno odbyć się poprzez włączenie do statystyk populacji nierolniczej wraz z tymczasowymi mieszkańcami miast, co pozwoliłoby na ukazanie realnego poziomu wielkości populacji miejskiej w obecnym miejscu zamieszkania (Kojima 1995). W większości przypadków miasta na poziomie prowincji oraz prefektury są znacznie większe niż obszary miejskie, a nawet metropolitalne, w najbardziej wiarygodnych definicjach (Demographia, Definition of Urban Terms 2008). Status miasta ma praktyczne znaczenie dla jego rozwoju, gdyż od niego zależą zasoby finansowe oraz poziom infrastruktury publicznej i usług socjalnych. Kryteria wyznaczania miast i ludności miejskiej często ulegały zmianie, przekładając się na niedokładne określenie poziomu urbanizacji całego kraju (ryc.1). Zmienne definicje miasta i metod ich wyznaczania oraz złożone metody zarządzania spisami, połączone ze skalą migracji, utrudniają też określanie poziomu urbanizacji regionów (Rubio, Linna 2013).

Ponadto, chińskie miasta w swoich granicach najczęściej zawierają rozległy obszar wiejski, w wyniku czego nie mogą być uznane za obszar wyłącznie miejski. Na przykładzie miasta wydzielonego (municipality), przedstawionego na ryc.1, możemy zauważyć, że nie obejmuje ono całości ludności utrzymującej się z dochodów pozarolniczych, a to zaniża wielkość populacji miejskiej. Sposoby wyznaczania ludności miejskiej ulegały kilkukrotnie zmianom. Początkowo (lata 1950-1963) za ludność miejską uznawano populację miasta właściwego. Następnie, od roku 1964 do 1981, ludność miejska klasyfikowana była jako nierolnicza populacja miasta właściwego (wąska definicja), natomiast w 1982 r. wrócono do poprzedniej definicji i stosowano ją do 1990 r. (ryc.1). Przyjęta w 1990 r. nowa zasada określania ludności miejskiej definiowała ją jako populację zamieszkującą obszary miejskie. Była to zarówno ludność z lokalnym miejskim zameldowaniem Hukou, jak i ta nieposiadająca go, lecz rezydująca w miastach przez przynajmniej rok przed danym spisem ludności. Ogólnie wszystkie dzielnice w miastach na poziomie prowincji i prefektury zaliczono 


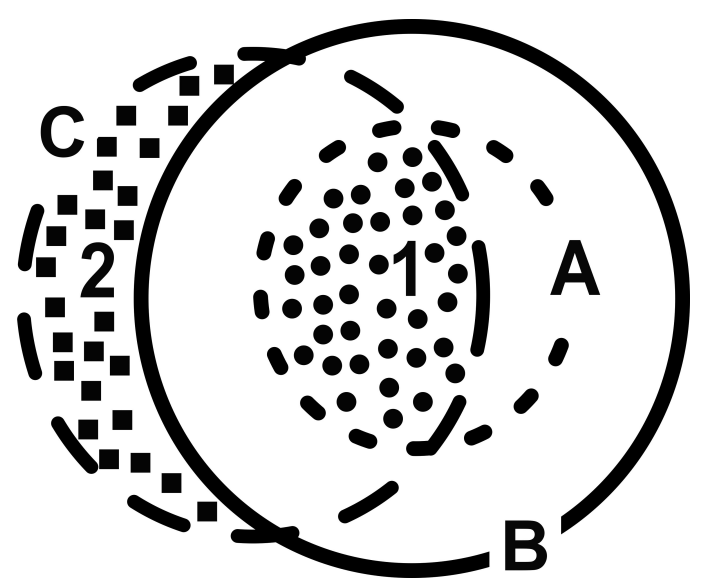

Ryc. 1. Różne metody obliczania liczby ludności na przykładzie miasta wydzielonego (najwyższego stopnia)

Fig. 1. Various methods of defining population number on the example of a municipality Objaśnienia:

A - granica miasta właściwego (city proper) - całkowita populacja miasta właściwego (TPC), kryterium używane do definiowania ludności miejskiej w latach 1950-1963 i 1982-1990;

B - granica miasta wydzielonego ( $w$ tym podmiejskie powiaty) - całkowita populacja miasta wydzielonego (TPM);

C - populacja nierolnicza w oparciu o klasyfikację gospodarstw domowych;

1 - nierolnicza populacja miasta (NPC), wąska definicja ludności miejskiej wykorzystywana w latach 1964-1981;

2 - ludność nierolnicza mieszkająca w powiatach poza miastem wydzielonym;

\section{Explanations:}

A - city proper boundary = total population of the city proper (TPC), used to define urban population in the years 1950-1963 and 1982-1990;

$\mathrm{B}-$ municipality boundary (including suburban counties) $=$ total population of the municipality (TPM); $\mathrm{C}$ - non-agricultural population based on the classification of households;

1 - non-agricultural city population (NPC), a narrow definition of urban population used in the years 1964-1981;

2 - non-agricultural population living in counties outside the municipality.

Źródto: opracowanie własne na podstawie Chan, Xu (1985).

Source: own study based on Chan, Xu (1985). 
jako „miejskie”, zaś w powiatowych ośrodkach miejskich - tylko obszary posiadające komitety mieszkańców. Definicja z 1990 r. była dość prosta i lepsza niż ta z 1982 r., lecz nadal obarczona była licznymi wadami. Oparcie definicji miasta na podstawie administracyjnej niosło za sobą wiele błędów, związanych ze źle odzwierciedlonymi granicami jurysdykcyjnymi miast, nieodpowiadającymi rzeczywistemu poziomowi urbanizacji (Chan, Hu 2003). Współcześnie bowiem wobec gwałtownej urbanizacji coraz więcej w granicach miast jest ludności nierolniczej, a obszary miejskie szybko rosną. Chińskie miasta są więc jednostkami administracyjnymi obejmującymi zarówno rdzeń miejski (city proper), czyli gęsto zaludniony i zurbanizowany obszar, jak i rozległe okalające go rejony rolnicze, słabiej zaludnione i zurbanizowane (Chan 2000).

Poważną barierą odzwierciedlającą problemy w badaniu chińskich obszarów zurbanizowanych jest też skomplikowany podział administracyjny miast. W ChRL miasta na szczeblu prefektury (prefecture level cities), na hierarchicznie niższym

Tab. 1. Liczba oraz struktura jednostek administracyjnych na poziomie powiatu w miastach wydzielonych dla lat 2005 i 2015

Tab. 1. Number and structure of administrative units at the county level within the municipalities for 2005 and 2015

\begin{tabular}{|c|c|c|c|c|c|c|}
\hline $\begin{array}{l}\text { Rok } \\
\text { Year }\end{array}$ & $\begin{array}{l}\text { Miasto } \\
\text { wydzielone } \\
\text { Municipality }\end{array}$ & $\begin{array}{c}\text { Liczba jednostek } \\
\text { na poziomie powiatu } \\
\text { Units at the county level }\end{array}$ & $\begin{array}{c}\text { Dzielnice } \\
\text { podlegające } \\
\text { jurysdykcji miast } \\
\text { Urban districts }\end{array}$ & $\begin{array}{l}\text { Powiaty } \\
\text { Counties }\end{array}$ & $\begin{array}{l}\text { Autonomiczne } \\
\text { powiaty } \\
\text { Autonomous } \\
\text { counties }\end{array}$ & $\begin{array}{c}\text { Miasta } \\
\text { na poziomie } \\
\text { powiatu } \\
\text { County level cities }\end{array}$ \\
\hline \multirow{4}{*}{2005} & $\begin{array}{l}\text { Pekin } \\
\text { Beijing }\end{array}$ & 18 & 16 & 2 & - & - \\
\hline & $\begin{array}{l}\text { Tiencin } \\
\text { Tianjin }\end{array}$ & 18 & 15 & 3 & - & - \\
\hline & $\begin{array}{l}\text { Czungking } \\
\text { Chongqing }\end{array}$ & 40 & 15 & . & . & 4 \\
\hline & $\begin{array}{l}\text { Szanghaj } \\
\text { Shanghai }\end{array}$ & 19 & 18 & 1 & - & - \\
\hline \multirow{4}{*}{2015} & $\begin{array}{l}\text { Pekin } \\
\text { Beijing }\end{array}$ & 16 & 16 & - & - & - \\
\hline & $\begin{array}{l}\text { Tiencin } \\
\text { Tianjin }\end{array}$ & 16 & 15 & 1 & - & - \\
\hline & $\begin{array}{l}\text { Czungking } \\
\text { Chongqing }\end{array}$ & 38 & 23 & 11 & 4 & - \\
\hline & $\begin{array}{l}\text { Szanghaj } \\
\text { Shanghai }\end{array}$ & 16 & 15 & 1 & - & - \\
\hline
\end{tabular}

Źródto: opracowanie własne na podstawie National Bureau of Statistics of China (stat.gov.cn).

Source: own study based on National Bureau of Statistics of China (stat.gov.cn). 
stopniu, zawierają w sobie m.in. miasta powiatowe (county level cities). Na przykład Changsha, miasto na poziomie prefektury i stolica prowincji Hunan, w podziale na szczeblu powiatowym obejmuje inne miasto - Liuyang (Demographia, Definition of Urban Terms 2008).

Miasta na wyższych poziomach administracyjnych mogą w swoich granicach mieścić dzielnice (inaczej dystrykty) miejskie, powiaty, miasta powiatowe oraz powiaty autonomiczne - tab.1. Przykładem są największe ośrodki miejskie Chin - cztery miasta wydzielone. Możemy zauważyć, że w 2005 r. w skład Pekinu wchodziło 18 jednostek powiatowych, z czego 16 było dzielnicami miejskimi, zaś dwa - powiatami. W 2015 r. stolica Chin składała się już wyłącznie z 16 dzielnic miejskich. Z kolei Szanghaj w 2005 r. pod swoją jurysdykcją miał 18 dzielnic miejskich i jeden powiat (łącznie 19 jednostek), zaś 10 lat później - już tylko 15 dzielnic i jeden powiat, czyli 16 jednostek (podobnie jak Tiencin). Jednak najbardziej skomplikowanym przykładem chińskiej administracji miejskiej jest Czungking, który w 2015 r. obejmował 38 jednostek powiatowych, w tym 23 dzielnice miejskie i 15 powiatów (w tym cztery autonomiczne). Dekadę wcześniej składał się on m.in z 15 dystryktów/dzielnic miejskich i czterech miast powiatowych (tab. 1). Wraz z rozwojem zjawisk urbanizacyjnych obszary miejskie rozlewają się na jednostki powiatowe, doprowadzając do włączania ich do dystryktów/dzielnic miejskich lub tworzenia z nich nowych jednostek.

Złożoność chińskich struktur miejskich dotyczy zarówno największych ośrodków miejskich, jak i miast na niższym szczeblu hierarchii jurysdykcyjnej. Typowe miasto na poziomie prefektury w obrębie administracyjnym składa się z miasta właściwego, obejmującego dzielnice/dystrykty miejskie, do którego przylegają suburbia dzielnice podmiejskie (ryc. 2A). Liczne wioski i miasteczka, zamieszkiwane na ogół jeszcze przez ludność rolniczą oraz inne mniejsze miasta, są także włączane do jurysdykcji prefekturalnych ośrodków miejskich. Miasta na poziomie powiatu mają podobną strukturę, skupiając również gminne miasteczka i wsie, a nawet mniejsze miejscowości. Obszar o najbardziej miejskim charakterze odgrywa rolę ścisłego centrum („miasto właściwe”), lecz nie jest złożony z dzielnic miejskich, tak jak miasta prefekturalne (ryc. 2B).

Na przykładzie czterech miast wydzielonych można uzyskać aż cztery różniące się między sobą dane dotyczące liczby ludności tych jednostek administracyjnych. Są to: populacja całkowita oraz miejska dla miasta wydzielonego, populacja obszaru miejskiego i miasta właściwego² (tab.2). Analizując je, zauważono, że w Szanghaju

\footnotetext{
${ }^{2}$ W Roczniku Statystycænym Rzeczypospolitej Polskiej (2018) w tab.10 (601) na 776-777 podano dane dla zespołów miejskich Chin za rok 2015, odpowiadające wariantowi D w tabeli 2, określając je terminem „zespół miejski” (ang. urban agglomeration).
} 
Tab. 2. Różnice w pozyskanych danych dotyczących populacji czterech miast wydzielonych dla lat 2005 i 2015

Tab. 2. Differences in the data obtained on the population of municipalities for 2005 and 2015

\begin{tabular}{|c|c|c|c|c|c|c|c|c|}
\hline \multirow{2}{*}{ Rok / Year } & \multicolumn{4}{|c|}{ Pekin / Beijing } & \multicolumn{4}{|c|}{ Tiencin / Tianjin } \\
\hline & A & B & C & D & A & B & C & $\mathrm{D}$ \\
\hline 2005 & 15380 & 12860 & 12991 & 11841 & 10430 & 7830 & 8430 & $\underline{9430}$ \\
\hline 2015 & 21710 & 18770 & 18421 & $\underline{13452}$ & 15470 & 12780 & 12516 & $\underline{10269}$ \\
\hline \multirow{2}{*}{ Rok / Year } & \multicolumn{4}{|c|}{ Szanghaj / Shanghai } & \multicolumn{4}{|c|}{ Chongqing / Czungking } \\
\hline & A & B & C & D & A & B & C & D \\
\hline 2005 & 18900 & 16840 & 17056 & $\underline{13603}$ & 27980 & 12650 & 9454 & $\underline{31692}$ \\
\hline 2015 & 24150 & 21160 & 23482 & 14430 & 30170 & 18380 & 13372 & $\underline{33718}$ \\
\hline
\end{tabular}

Objaśnienia: A - miasto wydzielone, B - ludność miejska w miastach wydzielonych, C - według WUP 2018 (obszar miejski), D - wyselekcjonowane miasto.

Explanations: A - municipality, B - urban population in amunicipality, C - according to WUP 2018 (urban area), D - selected city.

Źródto: Opracowanie własne na podstawie National Bureau of Statistics of China (stat.gov.cn) i United Nations, Department of Economic and Social Affairs, Population Division (2018). World Urbanization Prospects: The 2018 Revision.

Source: Own study based on National Bureau of Statistics of China (stat.gov.cn) and United Nations, Department of Economic and Social Affairs, Population Division (2018). World Urbanization Prospects: The 2018 Revision.

w 2015 r. samo miasto wydzielone liczyło ponad 24,1 mln osób, z czego ok. 21,2 mln klasyfikowano jako ludność miejską. Obszar miejski tej wielkiej metropolii skupiał natomiast ok. 23,5 mln osób, a miasto właściwe 14,4 mln. Stołeczne miasto wydzielone Pekin w 2015 r. zamieszkiwało 21,7 mln osób, lecz ludności miejskiej miało ono „tylko” ok. 18,8 mln. Obszar miejski stolicy liczył zaś 18,4 mln mieszkańców, zaś miasto właściwe tylko 13,4 mln (tab. 2). Po raz kolejny najciekawszym przykładem dużej rozbieżności danych był Czungking, gdyż według informacji podawanych przez Chińskie Biuro Statystyczne (NBSCh) w 2015 r. tę wydzieloną administracyjnie jednostkę zamieszkiwało ok 30,2 mln osób, lecz zaledwie 18,4 mln sklasyfikowano jako populację miejską. Raport World Urbanization Prospects: The Revision (WUP 2018) podaje, że w tym samym roku obszar miejski Czungkingu liczył 13,4 mln mieszkańców, a więc najmniej spośród wszystkich wartości, lecz populacja wyodrębnionego miasta osiągnęła w 2015 r. aż 33,7 mln osób, co oznacza, że Czungking było wtedy największym administracyjnym miastem Chin (tab.2). 
Czunking jest zresztą najczęściej wymienianym przykładem złożoności chińskich struktur miejskich, która zwróciła uwagę takich badaczy jak specjalista chińskiej urbanizacji Kam Wing Chan (2000, 2016) czy Yes Boquet z Francji (2009). Porównując wybrane dane dla miast wydzielonych w 2005 i 2015 r., możemy stwierdzić, że różnice w uzyskanych wartościach stopniowo zacierają się, jednak nadal stanowią duży problem w analizach urbanizacyjnych.

Omawiając złożoność urbanizacji Państwa Środka, nie sposób pominąć kwestii polaryzacji społecznej i podziału ludności. W Chinach od końca lat 50. XX w. obowiązuje system rejestracji gospodarstw domowych, zwany systemem Hukou, który dzieli mieszkańców ze względu na miejsce urodzenia na ludność miejską i wiejską. System rejestracji gospodarstw domowych przywiązuje Chińczyków do miejsca zamieszkania i bez zezwolenia nie pozwala na legalną migrację ze wsi do miast. Nie mogąc w sposób legalny zarejestrować swojej nowej miejskiej lokalizacji, migranci nie są uprawnieni do korzystania z miejskich praw, takich jak: opieka zdrowotna, pomoc społeczna i edukacja dzieci, a oprócz tego dotyka ich dyskryminacja związana z niższymi płacami i gorszymi warunkami sanitarnymi (Cai, 2012; Han 2017).

W okresie gospodarki socjalistycznej nierynkowej (od 1949 r. do końca lat 80. XX w.) skala migracji miejsko-wiejskich była znacznie ograniczona poprzez ścisłą kontrolę w postaci rygorystycznych zasad Hukou (Malik, Asmi i in. 2017). Reformy społeczno-gospodarcze Denga Xiaopinga skoncentrowały się na miastach wschodnich Chin, co wynikało z założenia tam specjalnych stref ekonomicznych (SEZ) oraz nowych otwartych miast nadbrzeżnych (COC). Zaowocowało to silną dysproporcją w rozwoju gospodarczym między wschodnimi i zachodnimi regionami Chin oraz uruchomiło gwałtowne migracje (Schneider, Benke 2014; Malik Asmi i in. 2017). Lata tego gospodarczego „otwarcia na świat” Chin przyniosły pozwolenie władz rządowych i lokalnych na przemieszczanie się mieszkańców wsi do miast - mimo utrzymywania ww. systemu Hukou. Ta cicha akceptacja wynikała z zapotrzebowania miast wschodnich Chin na tanią i wykwalifikowaną siłę roboczą dla powstających zagranicznych i narodowych przedsiębiorstw. Masowy i prawie niekontrolowany ruch migracyjny doprowadził do żywiołowego rozrostu miast (szczególnie na wschodnim wybrzeżu) oraz polaryzacji społecznej między mieszkańcami miast i migrantami ze wsi. Wobec przekształceń ekonomicznych Chiny doświadczyły masowej nielegalnej migracji wiejsko-miejskiej, która wpłynęła na konflikt, z jednej strony między mieszkańcami miast a mieszkańcami wsi, z drugiej między ludnością napływową w miastach a ich legalnymi rezydentami (Kamal-Chaoui, Leman i in. 2009). W analizie rzeczywistych rozmiarów populacji miejskiej tego kraju problemem jest więc nie tylko kwestia samej liczby mieszkańców obszarów miejskich, lecz także pytanie, czy wliczać do niej wiejskich migrantów.

Lu D. (2012) podaje, że w 1987 r. liczbę ludności napływowej ze wsi do miast szacowano na 15,2 mln osób, zaś w 2004 r. na 140 mln. Z kolei Du Y. i Wang M. 
Tab. 3. Liczba populacji migrującej wg różnych źródeł naukowych dla lat 1987-2012

Tab. 3. Number of migrating population according to various scientific sources for the years 1987-2012

\begin{tabular}{|c|c|c|c|}
\hline Autorzy / Authors & Rok / Year & $\begin{array}{l}\text { Liczba migrantów w mln } \\
\text { Number of in migrants in millions }\end{array}$ & $\begin{array}{l}\text { Uwagi } \\
\text { Comments }\end{array}$ \\
\hline \multirow{2}{*}{ Luo R.(2012) } & 2009 & 230 & \multirow{2}{*}{ - } \\
\hline & 2010 & 261,39 & \\
\hline \multirow{2}{*}{$\begin{array}{l}\text { Luchino Ch., } \\
\text { Lenci R. (2014) }\end{array}$} & 2012 & 260 & \multirow{2}{*}{ - } \\
\hline & $2050^{*}$ & 500 & \\
\hline \multirow{2}{*}{ Cai F. (2012) } & 2003 & 114 & \multirow{15}{*}{$\begin{array}{l}\text { na } 6 \text { miesięcy lub dłużej } \\
\text { for } 6 \text { months or longer }\end{array}$} \\
\hline & 2009 & 145 & \\
\hline \multirow{8}{*}{ Du Y., Wang M. (2012) } & 2001 & 84 & \\
\hline & 2002 & 104,7 & \\
\hline & 2003 & 113,9 & \\
\hline & 2004 & 125,8 & \\
\hline & 2003 & 132,1 & \\
\hline & 2007 & 136,5 & \\
\hline & 2009 & 140,4 & \\
\hline & 2009 & 154,3 & \\
\hline \multirow{5}{*}{ Lu D. (2012) } & 1987 & 15,2 & \\
\hline & 1990 & 30 & \\
\hline & 1995 & 56 & \\
\hline & 2000 & 80 & \\
\hline & 2004 & 140 & \\
\hline
\end{tabular}

*prognoza/forecast

Źródto: opracowanie własne na podstawie Luo (2012), Luchino, Ruggero (2014), Du, Wang (2012)

Lu (2012c).

Source: own study based on Luo (2012), Luchino, Ruggero (2014), Du, Wang (2012) Lu (2012c).

(2012) wskazują, że w 2001 r. populacja liczyła 84 mln osób, a osiem lat później już $154 \mathrm{mln}$. Luchino i Lenci (2014) oszacowali liczbę migrantów miejsko-wiejskich w 2012 r. na 260 mln osób, zaś według prognoz liczba ta osiągnie w 2050 r. aż $500 \mathrm{mln}$ (tab.3). Jeszcze inne dane wskazuje Chińskie Biuro Statystyczne (NSCh), które 
tzw. „płynną populację” (ang. floating population), czyli migrantów wiejsko-miejskich, oszacowało na $121 \mathrm{mln}$ osób w 2000 r. i 244 mln w 2017 r. Natomiast biorąc pod uwagę populację, u której występuje wspomniana już niezgodność rejestracji pobytu, liczbę tych migrantów NSCh określiło na 144 mln w 2000 r. i 291 mln w 2017 r. (ryc. 3).

NSCh podaje również, iż według wykonanych badań ankietowych w miastach wydzielonych w 2017 r. ludność z lokalnym Hukou stanowiła 50\% ogółu mieszkańców Pekinu, 67\% Tiencinu, 46\% Szanghaju i 74\% Czungkingu. Oznacza to, że co druga osoba w Pekinie i Szanghaju nie dysponowała lokalnym Hukou, była więc nielegalnym migrantem, w Tiencinie zaś i Czungkingu było to odpowiednio 2/3 oraz aż 3/4 liczby ludności. Kwestia migracji stawia dwa kluczowe pytania odnoszące się do ludności miejskiej Chin - pierwsze z nich dotyczy możliwości realnego określenia liczby przybyłych do miast migrantów wobec skali i dynamiki tego napływu, natomiast drugie brzmi: czy migrantów, pozbawionych miejskiego statusu, będących więc nadal mieszkańcami wsi, należy wliczać do miejskich statystyk i populacji.

\section{Wnioski}

Reasumując, należy podkreślić, że w Chinach nadal nie ma jednoznacznej, pełnej i uniwersalnej definicji miasta, gdyż najczęściej miasto, jego powierzchnię i populację odnosi się do granic administracyjnych miasta, obszaru miejskiego lub metropolitarnego. W Chińskiej Republice Ludowej problem właściwej delimitacji jednostek miejskich i ich ludności w ich realnych granicach jest niezwykle trudnym wyzwaniem z kilku istotnych powodów. Do najważniejszych z nich należą:

- wyznaczanie miast za pomocą dosyć zawiłych kryteriów społeczno-ekonomicznych; - ujmowanie ludności rolniczej w granicach jurysdykcyjnych jednostek miejskich;

- dwuznaczny podział administracyjny niesprzyjający tworzeniu klarownych statystyk;

-zmieniające się metodologie wyznaczania populacji miejskiej i obszarów miejskich;

- szybka dynamika w strukturze chińskiej urbanizacji, objawiająca się tworzeniem

rozległych struktur miejskich, takich jak aglomeracje policentryczne i monocen-

tryczne czy megalopolis, połączona ze słabo kontrolowanym napływem nielegalnej

ludności ze wsi na obszary miejskie;

- konflikt między ludnością migrującą do ośrodków miejskich a rezydentami miejskimi (Boquet 2009).

Oczywiście, istnieje kilka metod wyznaczania rzeczywistej ludności miejskiej, jedną z nich jest dodawanie populacji miejskich dzielnic, inną zaś oparcie się na kryteriach takich jak gęstość zaludnienia lub zabudowy (Chan 2016). Wypada jednak podkreślić, że dopóki rząd w Pekinie nie upora się z licznymi wyzwaniami natury metodologicznej, politycznej i społecznej, nie stworzy podstaw rzetelnej statystyki i definicji, kwestie właściwego wyodrębnienia ludności miejskiej i obszarów 
A.

\section{B.}

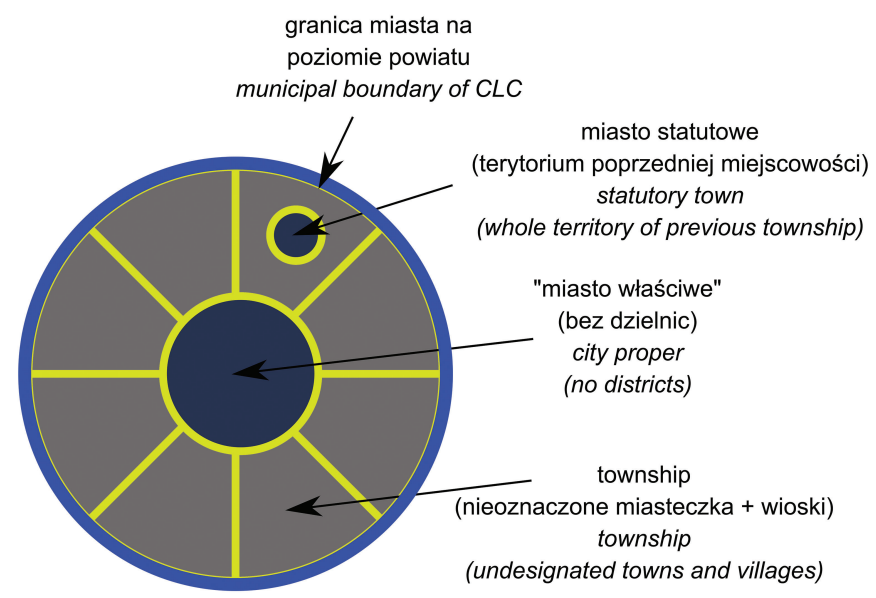

Miasto na poziomie powiatu County level city

miasto statutowe

(terytorium poprzedniej miejscowości)

statutory town

(whole territory of previous township)

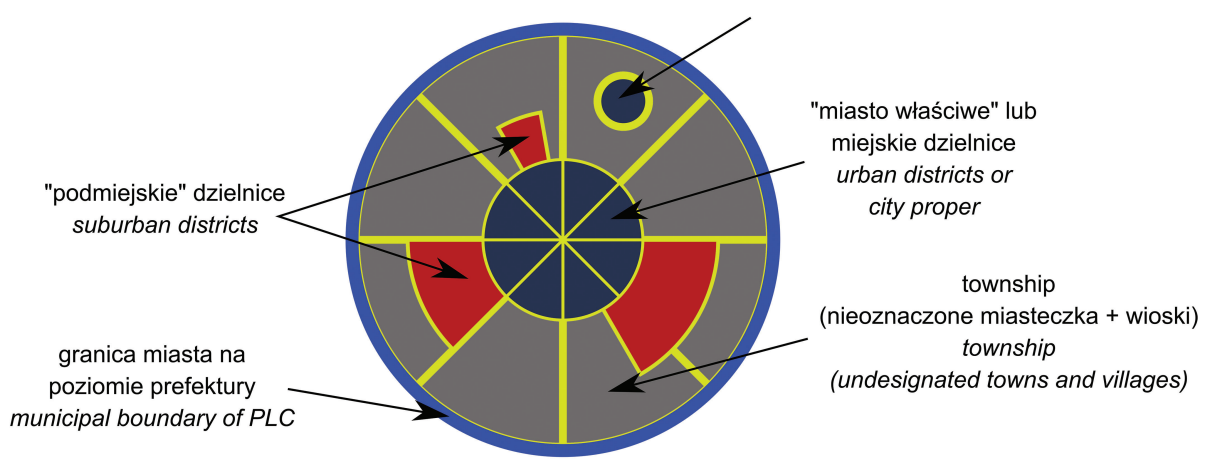

\section{Miasto na poziomie prefektury Prefecture level city}

Ryc. 2. Struktura chińskich miast na przykładzie jednostki miejskiej na poziomie prefektury i powiatu

Fig. 2. Structure of Chinese cities on the example of an urban unit at the prefecture and county level

Źródto: opracowanie własne na podstawie Kamal-Chaoui, Leman i in. 2009.

Source: own study based on Kamal-Chaoui, Leman i in. 2009. 


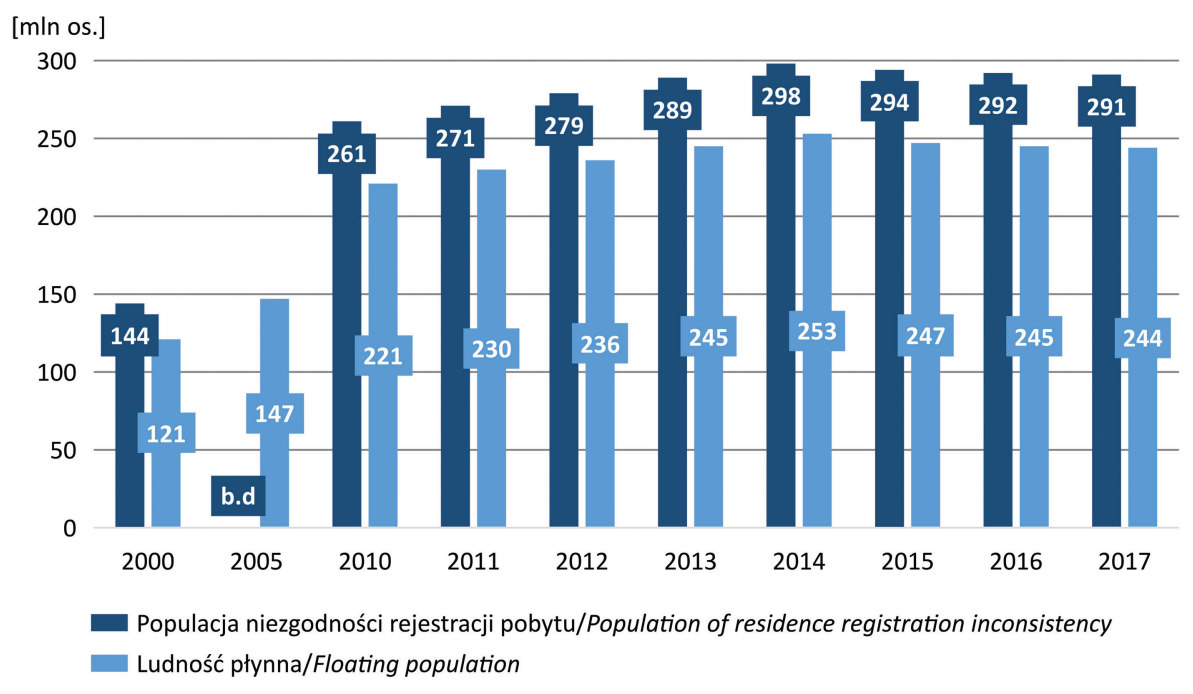

Ryc. 3. Liczba osób migrujących w Chinach w latach 2000-2017 według danych NBSCh Fig. 3. Number of people migrating in China in 2000-2017 according to NBSCh data

Źródto: opracowanie własne na podstawie National Bureau of Statistics of China (dostęp: 20.10.2019). Source: own study based on National Bureau of Statistics of China (access: 20.10.2019). 
miejskich będą poważnym problemem dla naukowców studiujących procesy urbanizacyjne w ChRL.

Należy zaznaczyć, że najbardziej efektywnymi metodami klasyfikacji ludności miejskiej będą te uwzględniające problematykę wiejskiej ludności napływowej, która na co dzień mieszka i pracuje na obszarach miejskich. Rozwiązanie tych kwestii nastąpi, gdy władze centralne na poziomie krajowym ostatecznie włączą migrantów miejskich w struktury społeczno-gospodarcze miast.

\section{Literatura:}

Boquet Y., 2009, Le taux d'urbanisation de la Chine, Espace, population, sociètès, 2009/3, 369-371. Bracken G., 2012, Introducion: Aspects of urbanization in China: Shanghai, Hong Kong, Guangzhou, [w:] G. Bracken (red.), Aspects of urbanization in China: Shanghai, Hong Kong, Guangæhou, Amsterdam University Press, Amsterdam, 13-18.

Cai F., 2012, Reform of The Hukou System and unification of rural-urban social welfare, [w:] F. Cai, M. Wang (red.), The China population and labor yearbook, Leiden, Brill Academic Pub, 287-304. Chan, K. W., 2000, The Problem with China's urban population data, Cities, 2005, 2006.

Chan, K. W., 2016, What is the true urban population of China? Which is the largest city in China, https://faculty.washington.edu/ (dostęp: 20.09.2019).

Chan K.W., Hu Y., 2003, Urbanization in China in the 1990s: New definition, different series and revised trends, The China Revies, Vol. 3, No. 2 (Fall 2003), 49-71.

Chan K.W., Xu X., 1985, Urban population growth and urbanization in China since 1949: Reconstructing a baseline, The China Quarterly, No. 104, 583-613.

Demographia World Urban Areas. Definition of Urban Terms, http://www.demographia.com (dostęp: 02.06.2019).

Du Y., Wang M., 2012, Population, industrial development, and employment in Chinese urbaniæation, [w:] F. Cai, M. Wang (red.), The China population and laboryearbook, Leiden, Brill Academic Pub, 189-214.

Eberhardt P., 2010, Procesy megaurbanizacyjne na swiecie, Roczniki Nauk Społecznych, t. 2(38), Towarzystwo Naukowe KUL \& Katolicki Uniwersytet Lubelski Jana Pawła II, 17-38.

Han Ch., 2017, Pracownicy migracyjni w Chinach, Time Marszałek Group, Toruń, 34-44.

Kamal-Chaoui L., Leman E., Rufei Z., 2009, Urban trends and policy in China, OECD Regional Development Working Papers, 2009/1, OECD publishing.

Kojima R., 1995, Urbaniæation in China, The Developing Economies XXXIII-2, 121-154.

Luchino Ch., Lenci R., 2014, Complementary strategies to Eco-cities for a new Chinese urbanization, Urban Futures - Squaring Circles: Europe, China and the World in 2050, Conference Proceedings.

Lu D., 2012, Demography, migration, and regional income disparity, [w:] D. Lu (red.), The Great Urbanization of China, World Scientific, Singapore, 301-316. 
Luo R., 2012, Across the institutional passage of migration: The Hukou system in China, InterDisciplines 1, 120-142.

Malik N., Asmi F., Ali M., Rahman M., 2017, Majorfactors leading rapid urbanization in China and Pakistan: A comparative study, Journal of Social Science Studies 2018, Vol. 5, No. 1, 148-168.

National Bureau of Sattistics of China, http://data.stats.gov.cn/(dostęp: 02.06.2019).

Rocænik Statystyczny Rzeczypospolitej Polskiej, 2018, Główny Urząd Statystyczny, Warszawa, 776-777.

Rubio H., Linna W., 2013, Challenges and opportunities facing China's urban development in the New Era, China Perspectives [Online], 2013/2, 17-30.

Schneider A., Mertes C. M., 2014, Expansion and growth in Chinese cities 1978-2010, Environmental Research Letters, 9 (2014), 1-11.

Szymańska D., 2015, Urbanizacja na świecie, [w:] D. Szymańska, M. Korolko. (red.), Inteligentne Miasta. Idea, Koncepcje $i$ Wdrożenia, Wydawnictwo Naukowe Uniwersytetu Mikołaja Kopernika, Toruń, 11-64.

United Nations, Department of Economic and Social Affairs, Population Division. World Urbanization Prospects: The 2018 Revision, https://population.un.org/wup/ (dostęp: 01.05.2019).

Zhang, H. K., Song S., 2012, Rural-urban migration and urbanization in China, [w:] D. Lu (red.), The great urbanization of China, World Scientific, Singapore, 279-300.

Mirostaw Wylon

Uniwersytet Mikotaja Kopernika w Toruniu

Wydziat Nauk o Ziemi i Gospodarki Przestrzennej

ul. Lwowska 1, 87-100 Torun

mirek.wylon@gmail.com 